\title{
Editorials
}

\section{Primary care and the climate and ecological emergency}

\section{WHAT SHOULD WE DO?}

When health professionals and organisations recognise the imperative of the climate and ecological emergency, this moves it into the highest-priority category for action: 'important and urgent'. After this dramatic labelling, actions often stall, perhaps being seen as 'too difficult' or 'for the attention of someone else'. In this timesensitive crisis, inertia is a mistake. Every day that we delay reaching net-zero carbon emissions increases the number of people who will suffer from the climate changes and raises the risks of an ecological collapse. 'This stark truth is why we need action now. Making changes that include what we eat, how we travel, and what we breathe will also have well-documented co-benefits for everyone's health. ${ }^{2}$ Primary care could and should be central to society's response to this emergency.

General practices are anchor institutions and GPs are trusted and respected in local communities. Both have the opportunity to be role models for low-carbon ways of living and working that protect planetary health and promote the same changes in their communities. In general practice we need to transform our work rapidly to become net-zero carbon practices. This means examining and changing almost everything we do. This will go far beyond the obvious issues of how we heat our buildings, what car we drive, and what we prescribe.

'It always seems impossible until it's done. (Nelson Mandela)

Primary care is already overburdened with expectations. Despite this, a thousand general practices use the Royal College of General Practitioners' (RCGP's) Green Impact for Health Toolkit, ${ }^{3}$ which has a hundred answers to the question "What should we do in general practice?' Seven years' experience with this toolkit suggests that there are three important blocks to progress. First, most practices find that it is unsustainable or unreasonable to take on extra unresourced work. Second, a lone enthusiast in a practice may try to make changes but can achieve little without support from others. Third, some practice teams make great progress with the majority of the tasks but get stuck with the complex challenges needed to become net-zero carbon practices.
If you want to go quickly, go alone. If you want to go far, go together.' (African proverb)

The above barriers suggest three areas for action. First, new resources are needed to fund the work to decarbonise primary care. We should be pressing the leaders who decide policy and budgetary priorities to provide these. Second, individuals need support from others to make change happen. They not only need support from their practices, but also from the local groups and networks that are emerging. These need help to grow. We should be telling our professional organisations such as the RCGP to promote these groups and networks. Third, the complex challenges need collaborative efforts to learn from the data, experience, and new ideas. We should be asking all our organisations that research, teach, and innovate what they are doing to help find and spread the best solutions faster.

Some of these actions are underway but must be increased and accelerated. For example, financial incentives for decarbonisation are being considered, Greener Practice networks are growing, with new local groups connecting all the time, and planetary health issues are being included in the teaching, training, and continuing education programmes. The RCGP webpage 'Sustainable development, climate change and green issues ${ }^{4}$ signposts many useful resources.

There is an opportunity as we emerge from the COVID-19 pandemic to build back better in every way. Ignoring the imperative to change can only worsen the crisis. General practices sit at the heart of our communities and we can influence and speed society's transformation to become more eco-centric than ego-centric.

In the end our greatest success as GPs could be as part of the solution and keeping the planet in good health for the benefit of all. 5

The opportunity is brief and there is much to be done. ${ }^{6}$ The first imperative is for everyone who cares to turn up and start.

\section{Terry Kemple,}

National Representative for Climate Change, Sustainability and Green Issues, Past President (2015-2017), RCGP, London.

\section{James N Smith,}

Assistant Director of Public Health Studies, Public Health Education Group, University of Cambridge. Cambridge.

\section{ADDRESS FOR CORRESPONDENCE}

\section{Terry Kemple}

Royal College of General Practitioners, 30 Euston

Square, London NW1 2FB, UK.

\section{Email: tjkempleagmail.com}

atkemple

\section{Georgie Sowman}

GP, North East England; Public Health England Physical Activity Clinical Champion, Newcastle upon Tyne.

\section{Angela Wilson}

GP, Oxford; Climate and Sustainability Lead for RCGP Thames Valley Faculty, London; Member, Healthcare Arts Collective.

\section{Jess Wynter Bee,}

Chair, Greener Practice Bristol, Bristol; RCGP Severn Faculty Climate and Sustainability Champion, Bristol; Salaried GP, Charlotte Keel Medical Practice, Easton, Bristol.

\section{Provenance}

Commissioned; not externally peer reviewed.

\section{Competing interests}

The authors have declared no competing interests.

DOI: https://doi.org/10.3399/bjgp21X717077

\section{REFERENCES}

. Intergovernmental Panel on Climate Change. AR6 climate change 2021: the physical science basis. 2021. https://uww.ipcc.ch/report/arb/wg1 laccessed 31 Aug 2021).

2. Watts N, Amann M, Arnell N, et al. The 2020 report of the Lancet Countdown on health and climate change: responding to converging crises. Lancet 2021; 397(10269): 129-170.

3. Green Impact. Welcome to Green Impact for Health. https://greenimpact.org.uk/giforhealth laccessed 31 Aug 2021).

4. Royal College of General Practitioners. Sustainable development, climate change and green issues. https://www.rcgp.org.uk/policy/ rcgp-policy-areas/climate-change-sustainabledevelopment-and-health.aspx laccessed 31 Aug 2021).

5. Kemple T. Planetary health and primary care: what's the emergency? Br J Gen Pract 2019; DOI: https://doi.org/10.3399/bjgp19X706145.

6. Greener Practice. Planetary health - how to start taking action. https://static1.squarespace. com/static/5e70ffa08cc1d3609c2cd386/t/61 162cc6f5674e01520d27f5/1628843207237/ Planetary+Health+Leaflet+.pdf laccessed 31 Aug 2021). 